\title{
Response to oxidative stress induced by cadmium and copper in tobacco plants (Nicotiana tabacum) engineered with the trehalose-6-phosphate synthase gene (AtTPS1)
}

\author{
Luisa Louro Martins • Miguel Pedro Mourato • \\ Sergio Baptista $\cdot$ Rafaela Reis $\cdot$ Florbela Carvalheiro $\cdot$ \\ André M. Almeida $\cdot$ Pedro Fevereiro $\cdot$ Ann Cuypers
}

Received: 29 March 2013/Revised: 2 November 2013/Accepted: 25 November 2013

(C) Franciszek Górski Institute of Plant Physiology, Polish Academy of Sciences, Kraków 2013

\begin{abstract}
The response of tobacco plants genetically engineered with the AtTPS1 gene to stress induced by excess $\mathrm{Cu}$ and $\mathrm{Cd}$ was evaluated in hydroponic solution (100 and $400 \mu \mathrm{M} \mathrm{Cu}$ and 50 and $200 \mu \mathrm{M} \mathrm{Cd})$ after a $48 \mathrm{~h}$ exposure. Two transgenic lines, transformed with the AtTPS1 (trehalose-6-phosphate synthase) gene from Arabidopsis, with different levels of trehalose-6-phosphate synthase expression (B5H, higher and $\mathrm{B} 1 \mathrm{~F}$, lower), and a wild type (WT) were investigated. Protein content, antioxidative enzymes (CAT, POD, SOD, and APX), glucose,
\end{abstract}

Communicated by G. Klobus.

L. L. Martins and M. P. Mourato contributed equally to the performed work.

L. L. Martins · M. P. Mourato ( $₫) \cdot$ S. Baptista $\cdot$ R. Reis UIQA, Instituto Superior de Agronomia, Universidade Técnica de Lisboa, Lisbon, Portugal

e-mail: mmourato@isa.utl.pt

F. Carvalheiro

Unidade de Bioenergia, LNEG-Laboratório Nacional de Energia

e Geologia, Lisbon, Portugal

A. M. Almeida

IICT-Instituto de Investigação Científica Tropical, Lisbon, Portugal

A. M. Almeida · P. Fevereiro

Instituto de Tecnologia Química e Biológica, Universidade Nova de Lisboa, Oeiras, Portugal

P. Fevereiro

Departamento de Biologia Vegetal, Faculdade de Ciências da Universidade de Lisboa, Lisbon, Portugal

\section{A. Cuypers}

Environmental Biology, Centre for Environmental Sciences, Hasselt University, Diepenbeek, Belgium fructose, lipid peroxidation, hydrogen peroxide and $\mathrm{Cd}$ and $\mathrm{Cu}$ contents were determined in leaves. The two transgenic lines were differently influenced by $\mathrm{Cd}$ and $\mathrm{Cu}$ exposure as they induced a different antioxidant enzymatic defense response. $\mathrm{B} 1 \mathrm{~F}$ and $\mathrm{B} 5 \mathrm{H}$ plants showed a better acclimation to $\mathrm{Cd}$ and excess $\mathrm{Cu}$ compared to WT. Furthermore B1F was more tolerant than $\mathrm{B} 5 \mathrm{H}$ to $\mathrm{Cd}$ and excess $\mathrm{Cu}$. B1F accumulated less $\mathrm{Cd}$ and $\mathrm{Cu}$ in leaves, probably due to a more efficient exclusion mechanism. Catalase was shown to be the most important enzyme in the antioxidative system of these plants.

Keywords Antioxidative enzymes - Cadmium . Copper - Oxidative stress $\cdot$ Tobacco

\section{Introduction}

Heavy metal pollution is an important cause of abiotic stress in plants that can limit crop productivity worldwide (He et al. 2005). Consequently, to improve plant tolerance to abiotic stresses to maintain productivity and plant production is of paramount importance. However, for successful development of new genotypes, it is essential to fully understand the overall mechanisms by which plants respond to a specific stress condition.

Plants exposure to toxic levels of heavy metals induce changes in physiological, biochemical and molecular mechanisms responsible for metal tolerance and acclimation (Apel and Hirt 2004; Clemens 2006; Sharma and Dietz 2009). The antioxidative defense system (both enzymatic and non-enzymatic) responsible for the removal of excess reactive oxygen species (ROS) is a plant physiological response that plays an important role in stress tolerance (Mittler 2002; Gratão et al. 2005; Gill and Tuteja 2010). 